\title{
Perbandingan Sistem Permodalan Konvensional dan Syariah Terhadap Pedagang Pasar Sentral Watampone dalam Pengembangan Usaha
}

\author{
Jusmayati \\ Institut Agama Islam Negeri (IAIN BONE) \\ jusmayati@gmail.com
}

ST Habibah

Sekolah Tinggi Agama Islam (STAl) Al -Furqan Makassar

sthabibah@gmail.com

\begin{abstract}
This study aims to find out how the comparison of conventional and sharia capital systems in business development. The author also examines the advantages and disadvantages of conventional and sharia capital. They are entitled to get a capital loan in accordance with the terms and agreements between the bank and the customer for the next stage. Traders have the right to what they want, whether they will be so-so or will develop their business with loan capital provided by the bank. The results of this study indicate that the capital system provided by bank financial institutions can help develop the merchant business, between conventional banks and Islamic banks have similarities and differences in providing loan capital to traders where banks use interest from these loans while Islamic banks use profit sharing not many sword owners choose a capital system with banks that use interest systems because conventional banks do not complicate customers differently than more complicated Islamic banks. So that people choose conventional banks that are already evident in the al-qur'an that interest equals usury.
\end{abstract}

Keywords: Conventional Capital, Sharia Capital, Comparison of Conventional Capital and Sharia Capital and Business Development.

\begin{abstract}
Abstrak
Penelitian ini bertujuan untuk mengetahui bagaimana perbandingan sistem permodalan konvensional dan syariah dalam pengembangan usaha. Penulis juga meneliti tentang kelebihan dan kekurangan permodalan konvnsionl dan syariah. Mereka berhak mendapatkan pinjaman modal sesuai dengan syarat dan kesepakatan antara pihak bank dan nasabah untuk tahap selanjutnya. Para pedagang mempunyai hak atas uasahanya, apakah akan begitu-begitu atau akan mengembangkan usahanya dengan modal pinjaman yang diberikan oleh bank. Hasil penelitian ini menunjukkan bahwa sistem permodalan yang diberikan oleh lembaga keuangan bank dapat membantu mengembangan usaha pedagang, dimana antara bank konvensional dan bank syariah memiliki kesamaan dan perbedaan dalam memberikan modal pinjaman
\end{abstract}

Jurnal Ilmiah Al Tsarwah

114

Program Magister Program Studi Ekonomi Syariah

Institut Agama Islam Negeri (IAIN) Bone 
kepada pedagang dimana bank menggunakan bunga dari kredit tersebut sedangkan bank syariah menggunakan bagi hasil tidak banyak pedangang memilih sistem permodalan dengan bank yang menggunakan sistem bunga karena bank konvensional tidak menyulitkan nasabah berbeda dengan bank syariah yang lebih rumit. Sehingga orang memilih bank konvenional yang sudah nyata dalam al-qur'an bahwa bunga sama dengan riba.

Kata kunci: Modal Konvensional, Modal Syariah, Perbandingan Modal Konvensional dan Modal Syariah dan Pengembangan Usaha.

\section{PENDAHULUAN}

Untuk mendirikan atau menjalankan suatu usaha diperlukan sejumlah modal( uang) dan tenaga ( keahilan). Modal dalam bentuk uang diperlukan untuk membiayai segala keperluan usaha, mulai dari biaya prainvestasi, pengurusan izin-izin, biaya investasi untuk pembelian aktiva tetap, sampai dengan modal kerja. sementara itu, modal keahlian adalah keahlian dan kemampuan seseorang untuk mengelola atau menjalankan suatu usaha. ${ }^{1}$ Modal adalah sejumlah dana yang ditanamkan kedalam suatu perusahaan oleh para pemiliknya untuk pembentukan suatu badan usaha dan dalam perkembangannya modal tersebut dapat susut karena kerugian ataupun berkembang karena keuntungan yang diperoleh. ${ }^{2}$

Besarnya modal yang diperlukan tergantung dari jenis usaha yang akan digarap. Dalam kenyataan sehari-hari kita mengenal adanya usaha kecil, usaha menegah, dan usaha besar masing- masing memerlukan modal dalam batas tertentu. Jadi, jenis usaha menentukan besarnya jumlah modal yang diperlukan. Misalnya jenis usaha pabrikan berbeda dengan pertanian. Hal lain yang mempengaruhi besarnya modal adalah jangka waktu usaha atau jangka waktu perusahaan menghasilkan produk yang diinginkan usaha yang memerlukan jangka waktu yang relatif besar pula. ${ }^{3}$

Modal sangat berperan penting dalam mengelola usahanya dengan tujuan agar usaha yang dijalankannya dapat berkembang sehingga dapat meningkatkan penjualan

1 M. Havidz Aima,dkk, Entrepreneurship \& Peluang Usaha, ( Jakarta: In Media, 2015), h. 229.

2 Sudarto, "Studi Pendapatan Pedagang Kecil Anggota KUD ditinjau dari Modal Usaha di Kecematan Sidoharjo Sragen", Jurnal pendidikan Ilmu Sosial, Vol.22, No.2, Desember 2012, 135-136.

3 M. Havidz Aima,dkk, Entrepreneurship \& Peluang Usaha ..., h. 233 
dan pendapatan. Namun modal yang sangat dibutuhkan oleh pengusaha tidak semuanya dapat dipenuhi dengan sendirinya, bahkan masalah modal inilah yang menjadi masalah bagi para pedagang, terutama pedagang kecil. Pedagang kecil umumnya kekurangan akan modal sehingga mengalami kesulitan dalam mengembangkan usahanya. ${ }^{4}$

Mengingat pentingnya peranan modal bagi perkembangan usaha untuk membantu para pedagang kecil untuk mendapatkan modal, maka pemerintah memberikan kebijaksanaan dengan mendirikan koperasi khusunya para pedagang kecil, dengan adanya kredit usaha kecil koperasi diharapkan membantu pengusaha dan pedagang kecil untuk tambahan modal yang dibutuhkan, dengan adanya tambahan modal tersebut dharapkan mampu mengembangankan dan memperlancar usahanya. ${ }^{5}$

Lembaga kredit jelas sangat dibutuhkan oleh masyarakat yang membutuhkan dalam menjalankan usahanya. Banyak jenis-jenis kredit yang menawarkan bantuan modal bagi masyarakat mulai dari bank, lembaga non bank maupun dari lembagalembaga lainnya.

Permodalan yang lemah dari masyarakat dapat diartikan sebagai suatu kekurangan kemampuan dari masyarakat untuk mengelola modal yang sebenarnya sudah ada dalam usahanya. Masyarakat dengan modal kecil ini cenderung menganggap apa yang dimilikinya adalah sesuatu yang biasa secara bebas digunakan. Hal ini juga tentunya terkait dengan permasalahan permodalan. ${ }^{6}$

Dalam pembangunan ekonomi Indonesia UKM selalu digambarkan sebagai sektor yang mempunyai peranan yang penting, karena sebagian besar jumlah penduduknya berpendidikan rendah dan hidup dalam kegiatan usaha kecil baik disektor tradisional maupun modern. Peranan usaha kecil tersebut menjadi bagian yang diutamakan dalam setiap perencanaan tahapan pembangunan yang dkelola oleh dua

${ }^{4}$ Sudarto, "Studi Pendapatan Pedagang Kecil Anggota

5 Sudarto, " Studi Pendapatan Pedagang Kecil Anggota..., h. 137

${ }^{6}$ Issabela Pratiwi Saragih, Analisis Pengaruh Modal Sendiri dan Modal Pinjaman Kredit Usaha Rakyat (KUR) Terhadap Pendapatan Pengusaha UMKM Kabupaten TobaSamosir (Studi Kasus: PT.Bank Sumut Cabang Balige)", Jurnal Ekonomi dan Keuangan, Vol.3, No.6, Oktober 2014, h. 394 
dapertemen yaitu; dapertemen perindustrian dan perdagangan, depertemen koperasi dan UKM. Namun demikian, usaha pengembangan yang telah dilaksanakan masih belum memuaskan hasilnya, karena pada kenyataannya kemajuanUKM sangat kecil dibandingkan dengan kemajuan yang sudah dicapai usaha besar. Pelaksanaan kebijaksaan UKM oleh pemerintah selama orde sedikit saja yang dilaksanakan, lebih banyak hanya merupakan semboyan saja, sehingga hasilnya sangat tidak memuaskan. pemerintah lebih berpihak pada pengusaha besar hampir semua sektor, antara lain perdagangan, perbankan, kehutanan, pertanian dan industri. ${ }^{7}$

Adapun salah satu pasar yang ada di Kab. Bone adalah Pasar Sentral, dimana para pedagang masih sulit dalam mengembangkan usahanya hal ini disebabkan karena masih kurangnya modal yang dimiliki, selain itu dalam memperoleh modal itu sendiri juga masih sulit misalnya modal pinjaman bank yang memerlukan dana besar untuk pengembaliannya karena beban bunga yang ada pada bank konvensional tetapi para pedangang lebih memilih bank tersebut dari pada meminjam modal melalui bank syariah yang menerapkan sistem bagi hasil, untuk mendapatkan pinjaman bank syariah dari sedikit rumit dengan berbagai persyaratan yang ada. Berdasarkan penjelasan di atas, maka perlu dilakukan penelitian lebih lanjut. Berdasarkan pada latar belakang masalah diatas maka penulis merumuskan permasalahan sebagai permasalahan pokok yang akan dibahas pada pembahasan selanjutnya. Rumusan masalah tersebut sebagai berikut: Bagaimana para pedagang pasar sentral dalam memenuhi kebutuhan permodalan dan Apakah kelebihan dan kekurangan sistem permodalan konvesional dan syariah.

\section{METODE}

\section{Jenis dan Pendekatan Penelitian}

Berdasarkan tempat penelitian, maka jenis penelitian yang digunakan adalah penelitian lapangan.

\footnotetext{
7 Jaidan Jauhari, Upaya Pengembangan Usaha Kecil Dan Menegah (UKM) Dengan Memanfaatkan E-Commerce, Jurnal Sistem Informasi, Vol.2, No.1, 7 Agustus 2017, h. 167 
Penelitian lapangan adalah atau field riset yaitu penelitian yang objeknya mengenai gejala-gejala atau peristiwa yang terjadi pada masyarakat yang dilakukan oleh peneliti dengan terjun langsung dengan objek penelitian untuk mengumpulkan data dan berbagai informasi. ${ }^{8}$

Sedangkan berdasarkan analisisnya, maka jenis penelitian yang digunakan pada penelitian ini adalah penelitian kualitatif.

Penelitian kualitatif merupakan penelitian tentang riset yang bersifat deskriptif dan cenderung menggunakan analisis.

Pendekatan yang digunakan adalah pendekatan ekonomi syariah yaitu salah satu alat analisis dalam memahami persoalan ekonomi syariah, yakni dimana untuk mengetahui sistem permodalan dalam pengembangan usaha.

2. Lokasi Penelitian

Penelitian ini bertempat dipasar sentral Watampone.

3. Data dan Sumber Data

a. Data Primer

Data primer merupakan jenis data yang diperoleh dari sumber utama (sumber asli), baik berupa data kualitatif maupun kuantitatif. Sesuai dengan asalnya dari mana data tersebut diperoleh, maka data ini sering pula disebut dengan istilah data mentah (raw data). ${ }^{9}$ Dalam hal ini, data primer merupakan data yang diperoleh langsung dari hasil wawancara yang diperoleh dari narasumber atau informan yang dianggap sangat berpotensi dalam memberikan informasi yang relevan dan sebenarnya di lapangan.

Data primer yang digunakan dalam penelitian ini diperoleh secara langsung dari objek / subjek penelitian. Selain itu, data primer dalam penelitian ini diperoleh pula dengan cara melakukan observasi di lokasi penelitian.

b. Data Sekunder

Data sekunder adalah jenis data yang diperoleh melalui hasil pengolahan pihak

8 Hadan Nawawi dan Mimi Ma rtini, Penelitian Terapan ( Yogyakarta: Gadjamada University Press), h. 24

9 Muhammad Teguh, Metodologi Penelitian Ekonomi: Teori dan Aplikasi, Ed. 1 (Cet. III ; Jakarta : RajaGrafindo Persada, 2005), h. 122 
kedua dari hasil penelitian lapangannya, baik berupa data kualitatif maupun data kuantitatif. Data ini sering pula disebut data eksternal. ${ }^{10}$ Data sekunder yaitu data yang erat kaitannya dengan penelitian yakni buku, website, artikel ilmiah, skrisi, dan literatur lainnya yang berhubungan dengan masalah yang akan diteliti.

4. Instrumen Penelitian

Instrumen penelitian adalah alat yang digunakan peneliti ketika melakukan proses pengumpulan data. Pemilihan jemis instrumen penelitian sangat tergantung kepada jenis metode pengumpulan data yang digunakan. Berhubung dalam penelitian ini menggunkan metode pengumpulan datanya adalah observasi atau pengamatan, maka instrumen yang digunakan berupa kamera, dan lain-lain. Dokumentasi dapat berupa catatan, buku, laporan kerja, arsip-arsip, gambar, foto, dan lain sebagainya.

Metode yang digunakan dalam mengumpulkan data-data tersebut, yaitu sebagai berikut:

a. Observasi

Observasi merupakan serangkaian aktivitas yang dilakukan oleh peneliti terhadap suatu proses atau objek dengan maksud untuk memahami pengetahuan dari sebuah fenomena/perilaku berdasarkan pengetahuan dan gagasan yang sudah diketahui sebelumnya. Observasi bisa diartikan sebagai suatu pengamatan yang dilakukan terhadap objek penelitian. ${ }^{11}$

Instrumen observasi dalam penelitian ini digunakan untuk menghimpun berbagai macam keterangan (data) yang dilakukan dengan cara melakukan pengamatan dan pencatatan secara sistematis terhadap sistem permodalan pedagang pasar sentral Watampone dalam pengembangan usaha.

b. Wawancara

Wawancara adalah pengumpulan data yang dilakukan dengan bertanya jawab

${ }^{10}$ Muhammad Teguh, Metodologi Penelitian Ekonomi: Teori dan Aplikasi, h. 121

${ }^{11}$ Hendri Tanjung dan Abrista Devi, Metodologi Penelitian Ekonomi Islam, Ed. 1 ( Cet. I; Jakarta: Gramata Publishing, 2013), h. 83 
langsung kepada responden. ${ }^{12}$

c. Dokumentasi

Dokumentasi merupakan instrumen yang digunakan untuk mendapatkan datadata primer dengan melalui data-data dari prasasti, naskah-naskah kearsipan (baik dalam bentuk barang cetakan maupun rekaman), artikel, data gambar / foto / blue print dan lain sebagainya. ${ }^{13}$

5. Teknik Analisis Data

Analisis data adalah upaya mencari dan menata secara sistematis catatan hasil observasi, wawancara, lainnya untuk meningkatkan pemahaman peneliti tentang kasus yang diteliti dan menyajikannya sebagai temuan bagi orang lain. ${ }^{14}$ Dalam pengertian lain disebutkan bahwa analisis data merupakan proses penyederhanaan data kedalam bentuk yang lebih mudah dibaca dan diinterprestasikan.

Dalam menganalisis data, penulis menggunakan teknik Descriptive Analysis. Descriptive Analysis merupakan suatu teknik analisa data, dimana penulis mengumpulkan data-data sesuai dengan yang sebenarnya, kemudian data-data tersebut disusun, diolah, dan dianalisis untuk dapat memberikan gambaran mengenai masalah yang ada. ${ }^{15}$

Sedangkan menurut Hadari Nawawi Descriptive Analysis merupakan langkahlangkah melakukan representasi objektif tentang gejala-gejala yang terkait dengan masalah yang diselidiki. ${ }^{16}$

\section{HASIL DAN PEMBAHASAN}

\footnotetext{
${ }^{12}$ Hendri Tanjung dan Abrista Devi, Metodologi Penelitian Ekonomi Islam, Ed. 1 ( Cet. I; Jakarta: Gramata Publishing, 2013), h. 93

${ }^{13}$ Supardi, Metodologi Penelitian Ekonomi \& Bisnis, (Cet. I ; Yogyakarta : Ull Press, 2005), h. 138

${ }^{14}$ Noeng Muhadjie Metode Penelitian Kualitatif, (Jakarta: Rake Sarasin, 2000) h.142

15Sugiyono, Metode Penelitian Kuantitatif, Kualitatif, dan R\&D, (Cet. I ; Bandung : Alfabeta, 2008), h. 105.

${ }^{16}$ Hadari Nawawi, Metode Penelitian Bidang Sosial, (Cet. IX ; Yogyakarta : Gajah Mada University Press, 2001), h. 63. 
Perbandingan Permodalan Konvensional dan Syariah Dalam Pengembangan Usaha

Berdasarkan hasil wawancara yang dilakukan pada pemilik usaha yang mendapatkan modal dari bank konvensional bahwa bank tidak memberikan sanksi tertulis jika telat membayar ansuran tapi akan diberitahu dengan mengubungi nasabah yang telat membayar ansurannya, tetapi apabila nasabah melewati jatuh tempo maka akan dikenakan denda sampai nasabah membayar ansurannya, jika masih nekat tidak membayar ansurannya akan dikeluarkan surat peringatan penyitaan jaminan. ${ }^{17}$

Apabila nasabah telah menyelesaikan pembayaran dengan pihak bank, kepercayaan bank terhadap nasabah yang bersangkutan akan hilang dan berdampak pada pengajuan nasabah kedepan. ${ }^{18}$

Sedangkan berdasarkan hasil wawancara yang dilakukan pada pemilik usaha yang mendapatkan modal dari bank syariah tidak jauh berbeda dengan modal yang didapatkan dari bank konvensional bahwa tidak ada sanksi tertulis jika telat membayar tapi diperingatkan untuk membayar jika tidak akan didenda tapi dendanyai tidak masuk dalam pendapatan akan tetapi masuk dalam pembukuan. Dimana denda yang dikenakan nasabah akan dimasukkan dalam dana sosial seperti ZIS (zakat, infaq dan shadaqah). ${ }^{19}$

Permodalan yang diberikan bank konvensional terhadap pedagang pasar sentral dapat mengembangankan usaha yang dijalankan karena dengan pinjaman yang diberikan kepada pihak bank untuk pedagang dapat memperbanyak barang. Sehingga akan menarik minat calon pembeli untuk mengunjungi toko, meskipun hanya sekedar melihat-lihat dan tidak jarang yang awalnya hanya melihat pada akhirnya tertarik untuk membeli barang tersebut. Sehingga akan terjadi pembelian ulang dengan barang yang berbeda dan orang akan ramai- ramai ke toko karena adanya berita dari satu orang ke Oktober 2017.

${ }^{17} \mathrm{H}$. Kahar Pemilik Toko Raihan,Wawancara oleh Jusmayati di Pasar sentral Watampone, 11

${ }^{18} \mathrm{H}$. Kahar Pemilik Toko Raihan,Wawancara oleh Jusmayati di Pasar sentral Watampone, 11 Oktober 2017.

19 Nurhayati, Pemilik Toko Yulia, wawancara oleh jusmayati di Pasar Sentral Watampoe, 12 Oktober 2017. 
orang lain bahwa ditoko raihan lengkap dengan apa yang dibutuhkan konsumen dengan banyak pilihan sehingga konsumen puas dan kembali mengunjungi toko. ${ }^{20}$

Begitupun dengan permodalan yang diberikan bank syariah terhadap pedagang pasar sentral dapat mengembangkan usahanya karena adanya modal yang memadai sehigga muncul hasrat untuk meningkatkan usaha dengan mampu menyediakan berbagai barang dagangan yang konsumen cari sesuai kebutuhannya. ${ }^{21}$

$\mathrm{Di}$ indonesia mayoritas muslim akan tetapi mereka lebih memilih bank konvesional dalam melakukan transaksi terutama dalam hal kredit. Dimana bank konvensional yang menerapkan sistem bunga (kredit) sebagaimana yang diketahui bahwa bunga bank adalah riba yang dilarang dalam islam. Sebagaimana ayat yang menjelaskan pada QS. AI-Baqarah ayat 275.

\section{Kelebihan dan Kekurangan Permodalan Konvensional Dan Syariah}

Berdasarkan hasil wawancara yang dilakukan pedagang pasar sentral, kelebihan menggunakan pinjaman modal pada bank konvensional ini dimana pengurusannya mudah dan cepat karena pinjaman modal usaha dari perbankan yang dapat membantu pedagang untuk menjalankan dana mnegembangkan usahanya hal ini menjadi salah satu alasan pedagang pasar sentral memanfaatkan jasa perbankan untuk modal usahanya, karena bank konvensional menawarkan berbagai macam kelebihan dan kemudahan bagi para pedagang yang membutuhkan modal usaha. ${ }^{22}$ Selain terjamin sisi hukumnya bank dapat menyalurkan dana dalam jumlah besar dengan prosedur yang relatif mudah dan proses pencairanya dikatakn tidak lama. Sedangkan kekurangannya menggunakan modal pinjaman konvensional menggunakan sistem bunga( riba). Selain itu bank konvesional tidak memperhatikan jenis usaha yang Oktober 2017.

${ }^{20} \mathrm{H}$. Kahar, Pemilik Toko Raihan,Wawancara oleh Jusmayati di Pasar sentral Watampone, 11

${ }^{21}$ Nurhayati , Pemilik Toko Yulia, wawancara oleh jusmayati di Pasar Sentral Watampone, 12 Oktober 2017.

22 H. Kahar, Pemilik Toko Yulia,Wawancara oleh Jusmayati di Pasar sentral Watampone, 11 Oktober 2017. 
dijalankan calon nasabah akan tetapi bank hanya melihat hasil atau pendapatan yang diperoleh nasabah agar tidak terjadi kredit macet. ${ }^{23}$

Berdasarkan hasil wawancara pedangang pasar sentral tentang kelebihan menggunakan modal pinjaman bank syariah akadnya yang sangat jelas, transparan dan sistem bagi hasilnya yang menjauhkan dari riba. Sedangkan kekurangan bank syariah yaitu terlalu berprasangka baik kepada semua orang sehingga banyak dari mereka yang beritikad tidak baik( tidak membayar ansuran). ${ }^{24}$

Dalam mengajukan pinjaman di bank syariah memiliki pesyaratan yang rumit sehingga calon nasabah lebih memilih untuk mengajukan pinjaman di bank konvensional ${ }^{25}$. Selain itu pengetahuan masyarakat tentang bank syariah masih minim dibandingkan dengan bank konvensional yang sudah lebih dulu dikenal oleh mayarakat padahal bank syariah menawarkan berbagai produk berdasarkan prinsip-prinsip islam agar masyarakat terhindar dari riba dan kesenjangan sosial.

\section{KESIMPULAN DAN SARAN}

\section{Kesimpulan}

Berdasarkan pemaparan diatas dapat disimpulkan sebagai berikut:

a) Sistem permodalan pedagang pasar sentral yaitu menggunakan permodalan konvensional dan syariah dimana permodalan yang diberikan oleh bank mampu megembangkan usaha para pedagang dengan memenuhi kebutuhan konsumen agar tidak berpindah kelain tempat, jika kebutuhannya terpenuhi maka konsumen akan datang untuk membeli barang yang berbeda ditempat yang sama.

\section{Oktober 2017.}

${ }^{23} \mathrm{Hj}$. Heryanti, Pemilik Toko Santi, Wawancara oleh Jusmayati di Pasar Sentral Watampone, 26

24 Nurhayati, Pemilik Toko Yulia, wawancara oleh Jusmayati di Pasar Sentral Watampone, 12 Oktober 2017.

${ }^{25}$ Hartati, Pemilik Toko Tati, Wawancara oleh Jusmayati di Pasar Sentral Watampone, 26 Oktober 2017. 
b) Pemberian modal oleh bank baik itu bank konvensional maupun syariah memiliki kelebihan dan kekurangan masing-masing. Bank konvensional yang sudah lama dikenal di masyarakat karena proses yang mudah dan cepat namun bank konvensional mempunyai kekurangan yaitu sistem bunga kredit dimana bunga disebut riba yang haram hukunya. Sedangkan bank syariah menggunakan sistem bagi hasil dimana untung dibagi rugi dibagi dan bank syariah terlalu berprasangka baik dan terpacaya pada semua nasabah sehigga tidak jarang nasabah mempunyai itikad tidak baik.

\section{Saran}

Berdasarkan saran penelitian dari penulis adalah sebagai berikut:

a) Diharapkan dengan adanya pinjaman modal berdampak positive bagi pedagang dalam meningkatkan pendapatannya sehingga usaha yang dijalankannya dapat berkembang bahkan maju dan dapat bersaing dengan yang lain dan membuka cabang ditempat lain.

b) Perlu adanya sosialisasi kepada masyarakat agar mereka mengetahui keunggulan-keunggulan mengambil pinjaman modal pada bank syariah serta mengetahui alur dan mekanisme pinjaman bank syariah dengan menggunkan akad mudharabah, murabahah, dan musyarakah.

\section{DAFTAR PUSTAKA}

Al-Quran dan Terjemahan, Bandung;Diponegoro, 2010

Abdul, Mannan, Muhammad. Ekonomi Islam: teori dan praktek (dasar-dasar ekonomi islam), Ed.1 [ t.c.]; Jakarta: Intermasa, 1992.

Aima, M. Havidz ,dkk. Entrepreneurship \& Peluang Usaha, Jakarta: In Media, 2015. Arsip Dokumentasi UPTD Pasar Sentral Palakka, Dokumentasi Oleh Penulis di UPTD Pasar Sentral Palakka, 11 Oktober 2017. 
Asasuri, Sofyan. Manajemen Pemasaran( Dasar Konsep \& Strategi) , Ed.1 cet.XIIII;Jakarta: Rajawali Pers, 2014.

Atun, Nur Isni. "Pengaruh Modal, Lokasi, dan Jenis Dagangan Terhadap Pendapata Pedagangan Pasar Prambanan Kabupaten Sleman"Penelitian, Fakultas Ekonomi Universitas Negeri Yogyakarta, 2016.

Deliarnov, Perkembangan Pemikiran Ekonomi, Ed. Revisi cet. XI; Jakarta: Rajawali Pers, 2015.

DH, Basu Swastha dan Ibnu Sukotjow. Pengantar Bisnis Modern, Ed. III, cet.XI; Yogyakarta: Liberty Yogyakarta, 2007.

H. Kahar , Pemilik Toko,Wawancara oleh Jusmayati di Pasar sentral Watampone, 11 Oktober 2017.

Hartati, Pemilik Toko Tati, Wawancara oleh Jusmayati di Pasar Sentral Watampone, 26 Oktober 2017.

Hasyim, Ali Ibrahim. Ekonomi Makro, Ed. 1 cet.l; Jakarta: Kencana, 2016.

Hj. Heryanti, Pemilik Toko Santi, Wawancara oleh Jusmayati di Pasar Sentral Watampone, 26 Oktober 2017.

https://Koinworks.Com/Home/Pinjaman, diakses 13 Oktober 2017

https://www.halomoney.co.id>blog>perbedaan bank syariah dan konvensional . di akses 05 Desember 2017.

Iqbal, Zamir dan Abbas Mirakhor. Pengantar Keuangan Islam, Ed. 1 cet. I; Jakarta: Kencana, 2008.

Jauhari, Jaidan , Upaya Pengembangan Usaha Kecil Dan Menegah (UKM) Dengan Memanfaatkan E-Commerce, Jurnal Sistem Informasi, Vol.2, No.1, 7 Agustus 2017, h. 167

Kasmir, Kewirausahaan, Ed.1cet.l;Jakarta:Raja Grafindo Persada, 2006.

Mardianti, Amelia, "Pengaruh Bagi Hasil dan Suku Bunga Bank Konvensional Pada Jumlah Deposito Mudharabah", Jurnal IImu dan Riset Akuntansi, Vol.5, No.7 Juli 2016, 17. 
Muhadjie, Noeng , Metode Penelitian Kualitatif, Jakarta: Rake Sarasin, 2000

Munir, Dasril, dkk. Kebijakan \& Manajemen Keuanagan Daerah, ( Yayasan Pembaruan Administrasi Publik Indonesia(YPAPI); Yogyakart,: 2004.

Nawawi, Hadan dan Mimi Martini, Penelitian Terapan ( Yogyakarta: Gadjamada University Press), h. 24

Nawawi, Hadari. Metode Penelitian Bidang Sosial, Cet. IX ; Yogyakarta : Gajah Mada University Press, 2001.

Nuraini. “Kemitraan BMT Bina Dhua'fa dengan Bakul Sayur Pasar Bringharjo dalam Peningkatan Usaha”, Penelitian, Yogyakarta, 2003.

Nurhayati, Pemilik Toko, wawancara oleh jusmayati di Pasar Sentral Watampone, 12 Oktober 2017.

Nurohman, Dede. Memahami Dasar-dasar Ekonomi Islam, cet. I; Yogyakarta: teras, 2011.

Partomo, Tiktik Sartika dan Abd. Rachman Soejoedono. Ekonomi Skala Kecil/Menengah \& Koperasi, cet. I; Bogor Selatan: Ghalia Indonesia, 2002

Paskarina, Caroline, dkk. "Evaluasi Kebijkan Pengelolaan Pasar Di Kota Bandung", Penelitian Bandung, 2007.

Pusat Pengkajian dan Pengembangan Ekonomi Islam, Ekonomi Islam, cet. V; Jakarta: Rajawali Pers, 2013.

S, Muh. Ali Musri. "Evaluasi Tingkat Pengelolaan Pasar Tradisional dan Analisis Tingkat Kepedulian Pedagang Terhadap Kebersihan Lingkungan di kota Medan( Studi Kasus Pasar Tradisional Kelas I-A)”. Penelitian, Medan, 2005. 